\title{
Long-period changes in the bottom water flowing through Vema Channel
}

\author{
Nelson G. Hogg \\ Department of Physical Oceanography, Woods Hole Oceanographic Institution, Woods Hole \\ Massachusetts \\ Walter Zenk \\ Institut für Meereskunde an der Universität Kiel, Kiel, Germany
}

\begin{abstract}
Further details of the "warming" of bottom water flowing through the Vema Channel, first reported by Zenk and Hogg [1996], are given. Because cross-channel gradients of temperature are large and the channel is narrow, careful analysis is required to determine whether or not the bottom water temperature minimum was adequately sampled by a particular station or cruise. During a period from 1972 to 1996 , at least 14 visits with quality hydrographic measurements have been made to the region. Of these, 11 were judged successful, and their data indicate an abrupt rise in potential temperature by $0.03^{\circ} \mathrm{C}$ from $-0.18^{\circ} \mathrm{C}$ to $-0.15^{\circ} \mathrm{C}$ in the early 1990 s that has remained until the latest observation in the spring of 1996. Although this observation is consistent with the report of warming of Antarctic Bottom Water in the Argentine Basin by Coles et al. [1996], their associated conclusion that this water mass has also freshened by $0.008 \mathrm{psu}$ (on potential density surfaces) is in contradiction with our finding of no measurable change.
\end{abstract}

\section{Introduction}

Long-term measurements of deep water characteristics in the ocean are rare and usually accomplished as transoceanic sections which are infrequent and badly aliased, both in space and time. Deep passages are believed to control the flow of bottom water between abyssal ocean basins [e.g., Whitehead, 1995] and are logical locations to monitor changes in bottom water characteristics. One such passage that has received regular attention since about 1972 is the Vema Channel, a deep connection between the Argentine and Brazil Basins of the western South Atlantic near $30^{\circ} \mathrm{S}$ and $40^{\circ} \mathrm{W}$ (Figure 1). Seven separate cruises to the area between 1972 and 1991 all observed that the coldest water flowing through the channel was remarkably stable at $-0.184 \pm 0.006^{\circ} \mathrm{C}$ potential temperature.

As a part of the Deep Basin Experiment (DBE) of the World Ocean Circulation Experiment (WOCE), a moored array was set across the Santos Plateau - Rio Grande Rise region in early 1991. It included finer spatial resolution within the Vema Channel. This array was recovered in late 1992, and hydrographic stations were made at each mooring site, both on deployment and recovery [Tarbell et al., 1994]. Although potential temperatures measured on deployment were consistent

Copyright 1997 by the American Geophysical Union.

Paper number 97JC00591.

0148-0227/97/97JC-0591\$09.00 with previous measurements, those on recovery indicated a warming of $0.03^{\circ} \mathrm{C}$ to $-0.15^{\circ} \mathrm{C}$, which appeared to continue rising to the level of $-0.13^{\circ} \mathrm{C}$ on a subsequent cruise [Zenk and Hogg, 1996]. Both hydrographic data and moored data were consistent in showing warming of the bottom water flowing not only through the Vema Channel and over the Santos Plateau to the west, but also the Hunter Channel to the east from current meters recovered $1 \frac{1}{2}$ years later.

Since these indications of warming were reported by Zenk and Hogg [1996], several more visits have been made to the Vema Channel. It is the intent of this paper to describe the further evolution of the phenomenon and to reassess the historic database.

\section{Cruises to the Vema Channel}

Although the Vema Channel was discovered during the Deutsche Atlantische Expedition of the 1920s (identified first as the "Rio Grande Rinne" by Maurer and Stocks [1933]) and hydrographic stations were made in its vicinity, the first station to penetrate to the depths of the channel was Geosecs station 59 made in November 1972 . Over the succeeding quarter century, at least 13 additional visits have been made, and two moored arrays have been deployed in the passage (see Table 1). The period since 1990 has been especially active as work has intensified in the Brazil Basin as part of the DBE.

Three locations along the channel axis have been favored by investigators. Early work (Geosecs, Cato and Chain 115) was concentrated near mid-length, just 


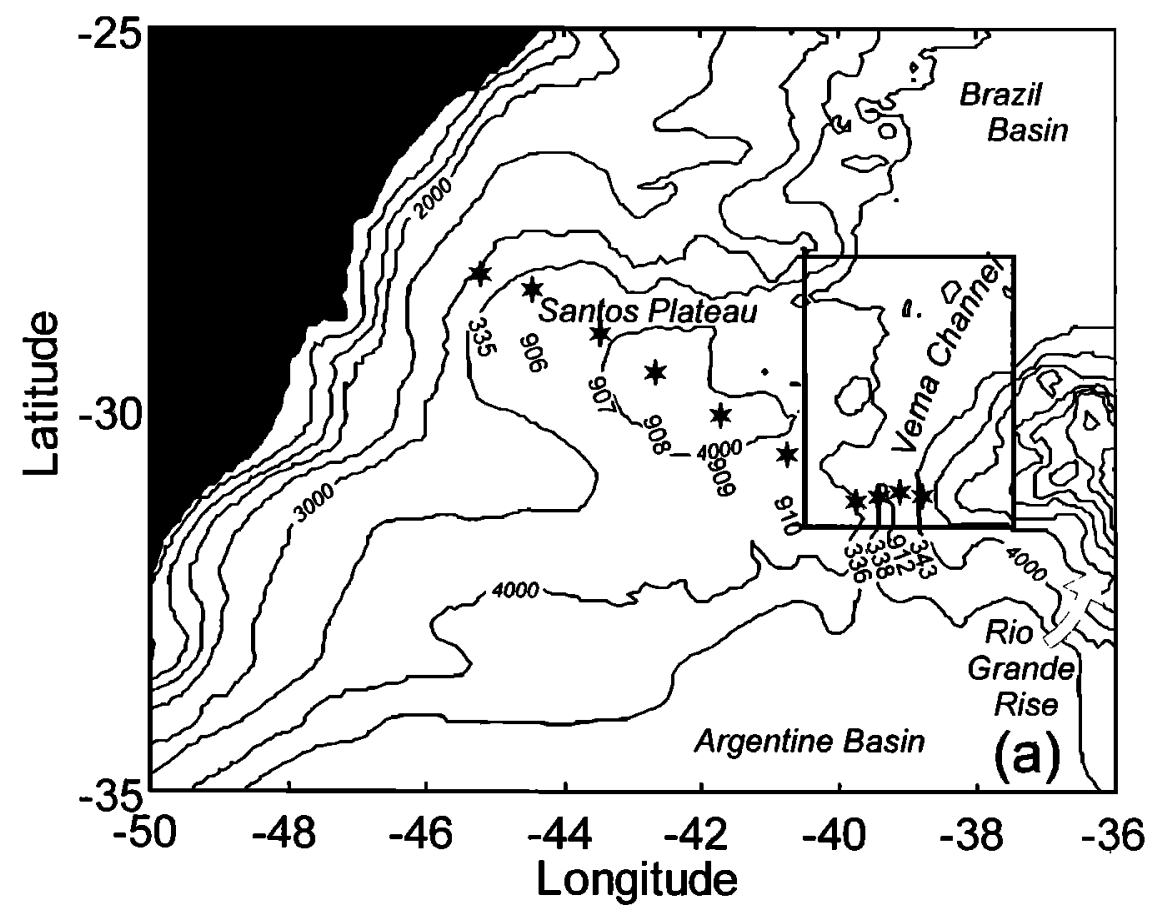

Figure 1a. The southern boundary region of the Brazil Basin showing the major topographic features and locations of moorings with instrumentation within the Antarctic Bottom Water layer.

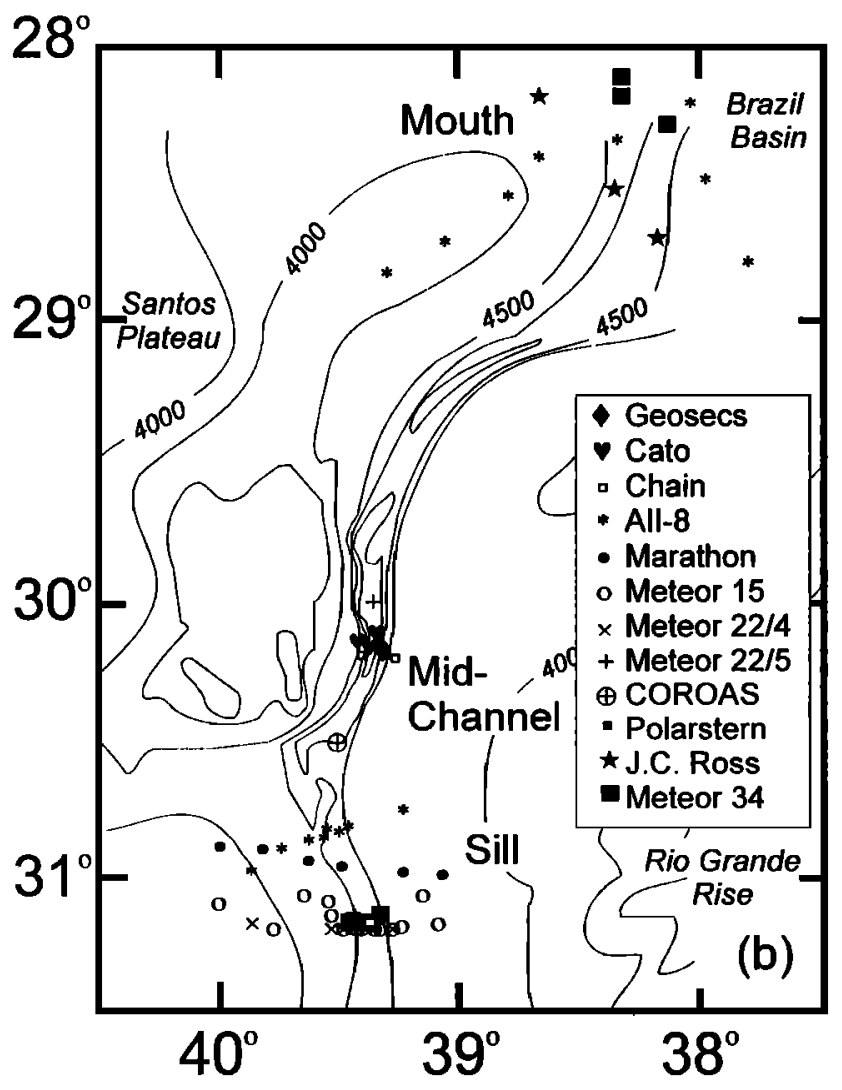

Figure 1b. Chart of the Vema Channel region (area within box in Figure 1a) showing hydrographic stations used in the analysis. The Vema Channel is the major conduit for exchange of bottom water between the Argentine and Brazil Basins. Symbols identify the different cruises that are used to construct Figure 3. north of where it splits into two branches $\left(\sim 30^{\circ} 10^{\prime} \mathrm{S}\right)$, and a single station was made at this location by $\mathrm{Me}$ teor 22 in 1993 as part of WOCE section A10. The most complete coverage was by Atlantis II 107 in 1980 with six sections covering the whole channel from its entrance in the Argentine Basin to its exit in the Brazil Basin. The exit section $\left(\sim 28^{\circ} 15^{\prime} \mathrm{S}\right)$ has been visited twice since then. The Meteor 15 cruise, the first to have swath bathymetric capability, identified the location of the sill [Zenk et al., 1993] and occupied a finely resolved section at this latitude $\left(\sim 31^{\circ} 12^{\prime} \mathrm{S}\right)$ as well. This was near where the Thomas Washington Marathon Cruise (leg 8) traversed the channel in late 1984 [Zemba, 1991], and this section has been revisited another four times ( $\mathrm{Me}$ teor 22 and 34, COROAS I, and Polarstern ANT XII).

In this report we are focusing on the temperature and other properties of the coldest water mass flowing through the Vema Channel, identified by Reid et al. [1977] as Weddell Sea Deep Water, the most dense component of what is popularly known as Antarctic Bottom Water (AABW). This is a small lens of relatively homogeneous water found along the eastern wall of the channel, when within the channel, but along the western boundary otherwise [Johnson et al., 1976; Hogg et al., 1982]. As few of the visits to the region have made highly resolved sections (Table 1) and cross-channel gradients are large (Figure 2), it is first necessary to assess the station positions with respect to this core layer.

The early Vema Channel work predates the availability of accurate navigation. Because the east-west dimensions of the eastern wall of the Vema Channel are just a few kilometers, the bottom depth is often a better indication of location than recorded station position. 
Table 1. Cruises and Expeditions to the Vema Channel

\begin{tabular}{lccc}
\hline Cruise/Expedition & Date & $\begin{array}{c}\text { Number of } \\
\text { Stations } \\
\text { Used }\end{array}$ & Comments \\
& & & \\
DAE & Aug. 1925 & $4(43-46)$ & Deutsche Atlantische Expedition \\
Geosecs, leg 6 & Nov. 1972 & $1(59)$ & \\
Cato, leg 6 & Nov. 1972 & $3(13,14,51)$ & \\
Chain 115, leg 6 & April 1974 & 4 & used a "thermograd" [Johnson \\
& & & et al., 1976] \\
AII-107, leg 2 & Oct. 1979 & $1(76)$ & \\
AII-107, leg 8 & May 1980 & $12(111-118)$ & includes a "yo-yo" \\
Marathon, leg 9 & Nov. 1984 & 5 & \\
Meteor 15, leg 1 & Jan. 1991 & 13 & \\
Meteor 22, leg 4 & Dec. 1992 & 7 & part of WOCE section A11 \\
Meteor 22, leg 5 & Jan. 1993 & 1 & Brazilian WOCE contribution \\
COROAS I & March 1993 & $1(24)$ & \\
COROAS II & March 1994 & $1(220)$ & \\
Polarstern ANT XII & Nov. 1994 & 1 & part of WOCE section A23 \\
James Clark Ross 10 & May 1995 & 3 & \\
Meteor 34, leg 3 & March 1996 & 6 & \\
\hline
\end{tabular}

In any case, these deep flows are highly constrained by the bottom topography and tend to follow bottom contours. For our purpose we will use geographic position solely as an indicator of whether a station was made to the east or west of the channel axis.

\section{Time Changes}

Aboard the Meteor in late 1992 it was clear from comparison of the hydrographic data obtained on the deployment and recovery cruises that a significant warming had occurred in the bottom water. Although this subject has been dealt with elsewhere [Zenk and Hogg, 1996], we will update and add to that treatment by showing that there is an associated weakening of the velocity field (section 5) within the AABW and give more details on the structure of the warming trend within the Vema Channel.

One of the pieces of evidence cited by Zenk and Hogg [1996] was the change in the coldest temperature to be observed within the Vema Channel at various times over the past 20 years, beginning with Geosecs station 59 in 1972. Because there are substantial cross-channel temperature variations in thermal wind balañce with the strong velocity shears, the assessment of temporal change is difficult to separate from spatial variation, especially for isolated stations or coarsely sampled sections. Within the confines of the channel, Hogg et al. [1982, Figure 12] (see also Figure 2) have shown that the coldest water is banked to the right (looking downcurrent to the north), while at the entrance and exit, the opposite is true. A similar configuration is also seen in the Hunter Channel [Speer and Zenk, 1993] and the Vema Fracture Zone in the Mid-Atlantic Ridge at $11^{\circ} \mathrm{N}$ [McCartney et al., 1991]. Hogg et al. [1982] also found no substantial change in the coldest water along the full length of the channel, some $400 \mathrm{~km}$, although even colder water $\left(\sim-0.195^{\circ} \mathrm{C}\right)$ was found on the most southern transect which reached southward into the Argentine Basin.

In order to locate the extremum of bottom potential temperature with respect to the expected location of the cold lens on particular cruises, we have plotted bottom temperature versus height above the channel axis depth as defined by the deepest station at that locale (Figure 3). The depth is multiplied by the sign of the distance east of the channel axis: as stated previously, we

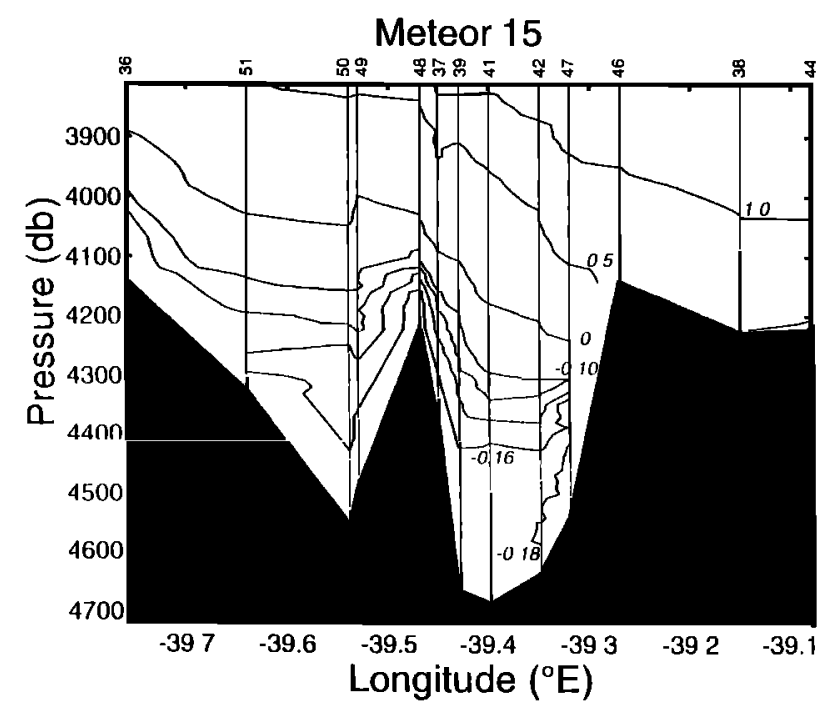

Figure 2. A "typical" highly resolved cross section of potential temperature from within the Vema Channel. This is constructed from the Meteor 15 data set but is similar to that obtained by AII-107 [Hogg et al., 1982, Figure 12]. Note the location of the temperature minimum on the eastern wall of the passage. 

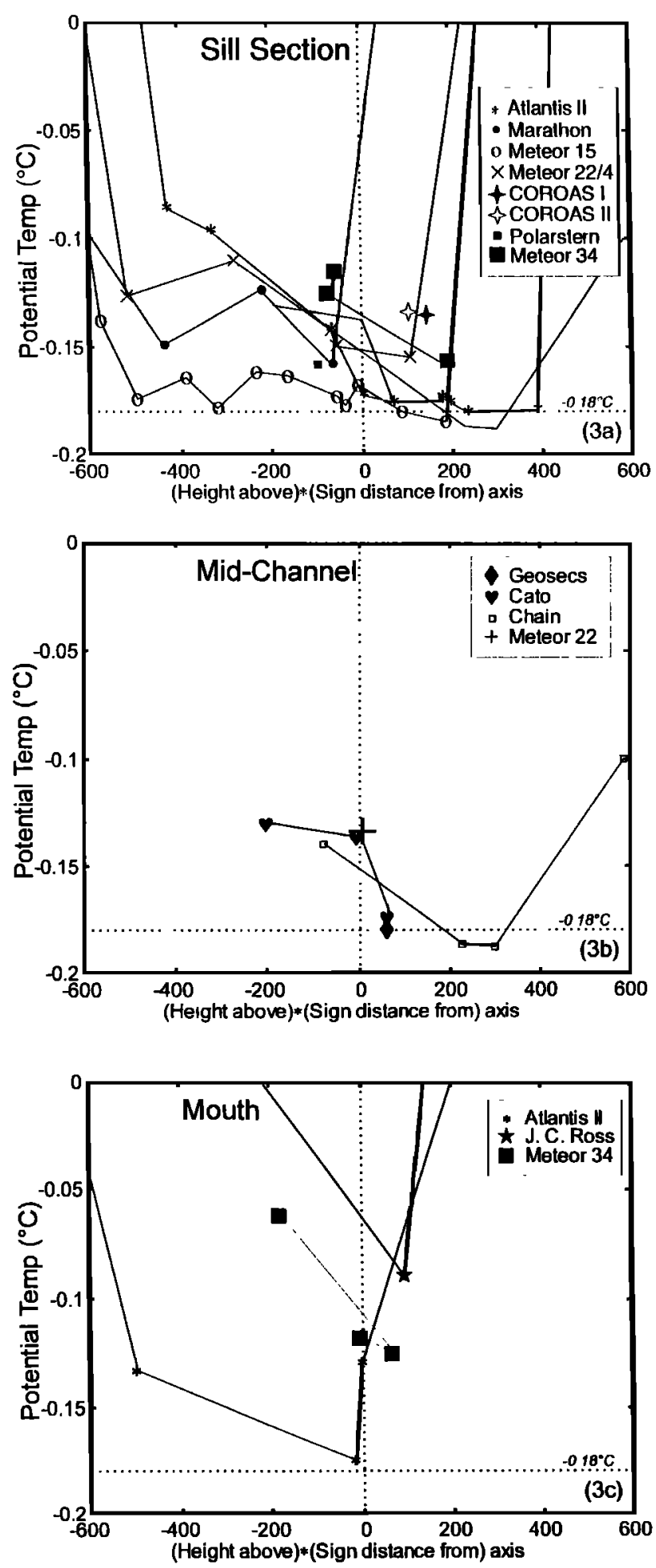

Figure 3. Potential temperature at the bottommost point (typically $10 \mathrm{~m}$ above actual bottom) for stations on indicated cruises versus the height of the bottom above the axis depth (in meters) multiplied by the sign of the zonal displacement of the station from the axis. The locations of the stations can be cross referenced with Figure 1, where the same symbols are used. (a) For sections and stations near the Vema Channel sill. (b) For sections and stations near midlength of the Vema Channel. (c) For sections and stations at the northern exit or mouth of the Vema Channel. use this abscissa, as older cruises did not have the navigational control of modern cruises, whereas their depth sounding was quite accurate. Plots of bottom temperature versus this measure at the three well-sampled sections are shown in Figure 3 . Although the deepest point of a cast is usually more than $\mathbf{5} \mathrm{m}$ above the bottom and varies from cruise to cruise, this variability is not particularly important in the Vema Channel, where thick, nearly homogeneous layers are usually present.

Sections at the sill transect (Figure 3a) have optimal spatial resolution, AII-107 and Meteor 15 being the best of those. Consistent with Figure 2, we see that temperature reaches its minimum value just to the east of the channel axis before it abruptly increases, a feature resulting from the precipitous change in bottom depth of several hundred meters over a short distance. We can also see that the other cruises sampled this cold lens with varying degrees of success. For example, the Thomas Washington Marathon cruise, although generally well resolved, failed to make a station to the east of the axis, and its bottom temperatures lie between those of AII-107 and Meteor 15 elsewhere. However, Meteor cruise 22 was successful in this endeavor, and the $0.03^{\circ} \mathrm{C}$ temperature rise, so indicated, is the basis for Zenk and Hogg's [1996] conclusion of a warming trend. The latest sample comes from Meteor 34 in early 1996 and indicates that the warming has ceased and the coldest water has leveled off at $-0.157^{\circ} \mathrm{C}$. The warmest station, to the east of the axis, belongs to the Brazilian COROAS II cruise and was obtained in March 1994.

The differences between the AII-107 and Meteor 15 distributions (Figure 3a) probably reflect their different locations along the channel, with Meteor 15 being farther south at the sill and AII-107 somewhat downstream of that dynamically important location (Figure 1). Hydraulic models [e.g., Hogg, 1983] show that the flow makes a transition from subcritical to supercritical at the sill and an abrupt change occurs in the isopycnal configuration.

The Geosecs station was made farther to the north near where three other cruises have worked in the Vema Channel (Figure 3b). At this locale, Chain 115 [Johnson et al., 1976] is the best resolved and includes two stations with potential temperatures slightly less than $-0.18^{\circ} \mathrm{C}$ to the east of the axis. Geosecs station 59 and one of the three Cato stations also sampled to the east of the axis and measured similarly cold bottom temperatures. As part of the A10 WOCE section at $30^{\circ} \mathrm{S}$, Meteor 22 made a single station within the channel. Although this was very near the deepest part of the channel, its warm temperature $\left(-0.135^{\circ} \mathrm{C}\right)$ is close to that of a similarly located Cato station, indicating that it failed to penetrate the cold lens and should not be included in our time series.

In May 1995, the RRS James Clark Ross occupied a section (WOCE A23) across the exit of the Vema Channel [Heywood and King, 1996], nearly coincident with another section of the Hogg et al. [1982] program (Figure 3c). Although the earlier cruise continued to measure a minimum of $-0.180^{\circ} \mathrm{C}$ at this location, by 


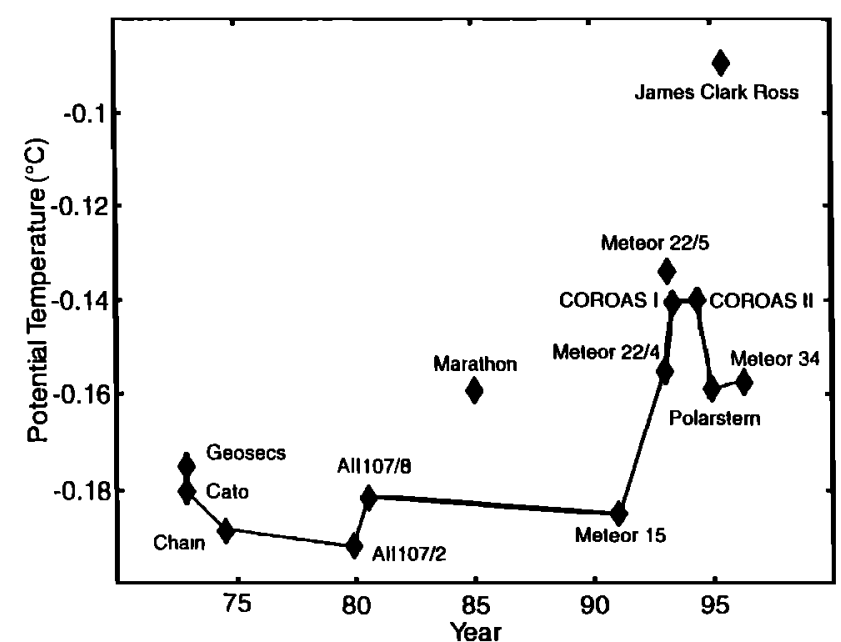

Figure 4. Time series of temperature of the cold Weddell Sea Deep Water lens found within the Vema Channel. Only those measurements that can be located within the expected location of this lens are connected by line segments. The other three points are warmer because they appear to be to the west of the channel axis and not in the lens (see text).

the time of the later cruise, the coldest temperature was just $-0.09^{\circ} \mathrm{C}$, an increase of $0.09^{\circ} \mathrm{C}$ that is consistent with continued warming at the rate of about $0.015^{\circ} \mathrm{C} / \mathrm{yr}$ that was reported by Zenk and Hogg [1996]. However, it would appear from Figure $3 \mathrm{c}$ that neither this section nor a later one by Meteor (34) unambiguously sampled the cold lens.

The coldest potential temperatures from all 13 Vema Channel cruises are plotted as a time series in Figure 4. For reasons outlined above, we believe that those data from three of these failed to sample the cold lens: the Thomas Washington Marathon cruise, Meteor 22/5, and the James Clark Ross A23 WOCE section. Connecting the remaining 10 with line segments, we see an abrupt transition from $-0.18^{\circ} \mathrm{C}$ to $-0.15^{\circ} \mathrm{C}$ around 1992.

\section{Supporting Time Series}

Zenk and Hogg [1996] presented measurements by moored current meters of temperature near the axis of the Vema Channel at the sill position. The two deepest such measurements, converted to potential temperature, are reproduced in Figure 5a. The absolute calibration is certainly no better than $\pm 0.01^{\circ} \mathrm{C}$, rendering the inversion that appears early in the record of unlikely significance. It is apparent that the deepest instrument suffers from a near linear drift, which has now been verified by a postcruise calibration. However, over the nearly 2 years of observation the coldest temperatures at both levels are at the beginning of the record, and temperatures warm by $\sim 0.03^{\circ} \mathrm{C}$ during the nearly 2-year record. Consistent with the discrete hydrographic sampling at the beginning and the end by the Meteor, the potential temperature rises from a minimum near $-0.18^{\circ} \mathrm{C}$ and ends the period closer to

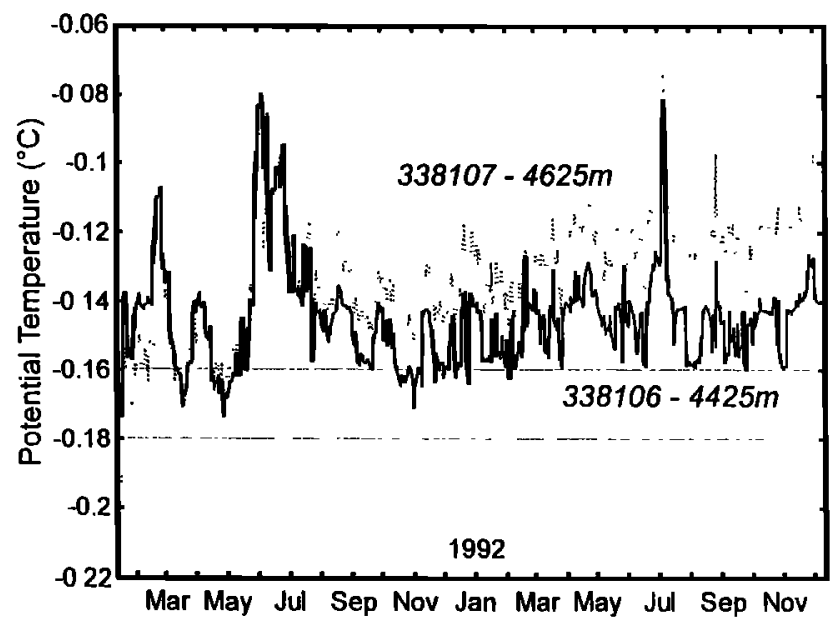

Figure 5a. Current meter time series of temperature for the deepest two instruments on a mooring located at the Vema sill during 1991 and 1992. The deeper instrument suffers from nearly linear sensor drift, but both suggest that the warming of $0.03^{\circ} \mathrm{C}$ may have occurred in just a few months at the beginning of the record. The first three digits of the instrument number give the mooring number, and the last digit the sequential number of the instrument on the mooring.

$-0.14^{\circ} \mathrm{C}$. This change occurs at a variety of timescales and could be interpreted as either a quick transition in the first 5 months or a more gradual drift with shorter timescale fluctuations. For comparison, an earlier 1981 record at about the same depth and a position near the axis a little to the north is shown in Figure 5b [see Hogg et al., 1982]. Although the calibration uncertainties are comparable to the differences in these two records, the earlier record is about $0.02^{\circ} \mathrm{C}$ colder than the later, on average.

\section{Discussion}

Coles et al. [1996] discuss similar and possibly related changes farther upstream in the Argentine Basin

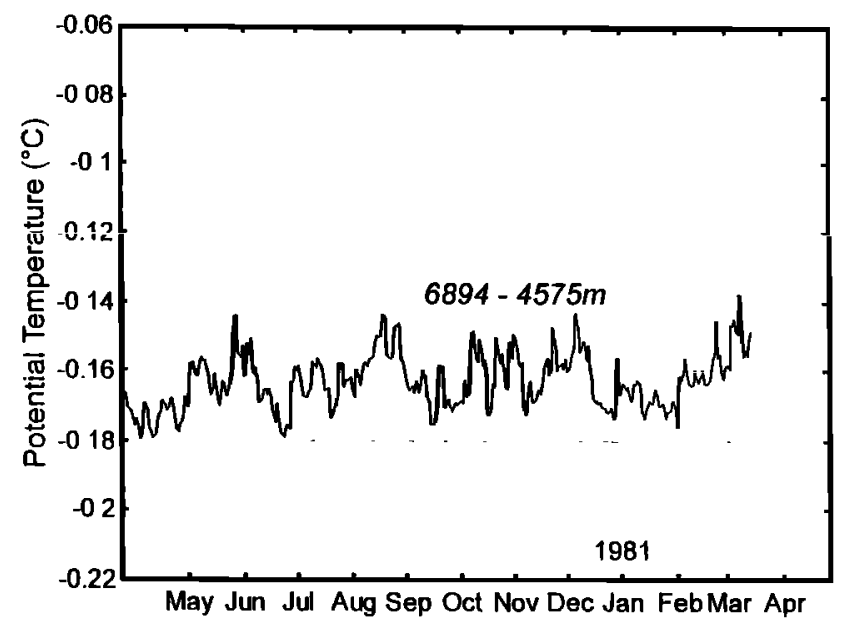

Figure 5b. As in Figure 5a except for an earlier 1981 record obtained a little to the north along the axis. 


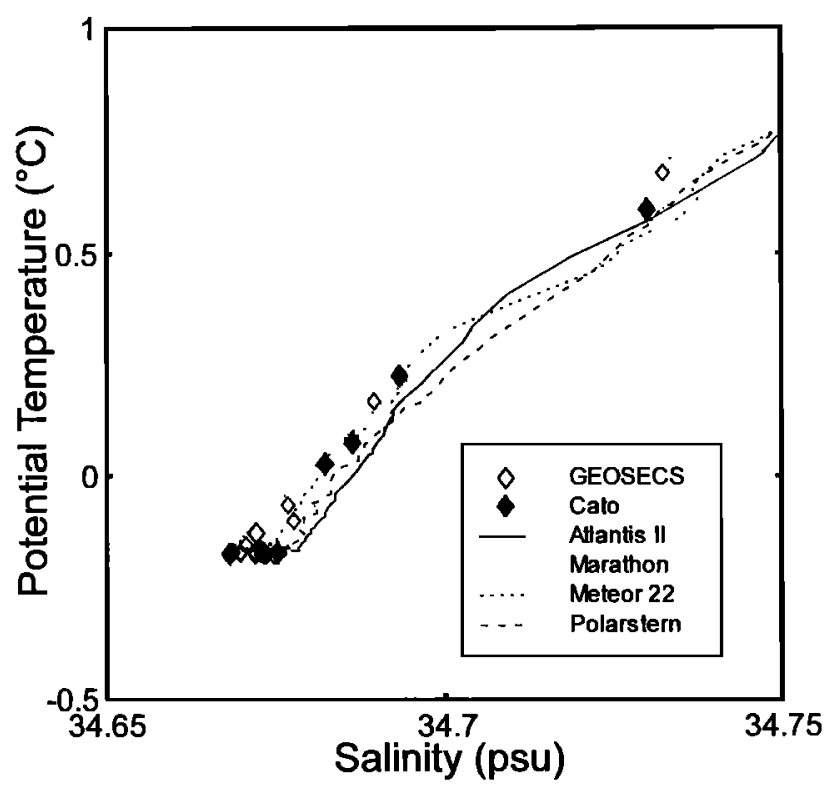

Figure 6a. $\theta-S$ plots for selected stations within the Vema Channel near its axis. See text.

determined from a comparison of historical data (early 1980s) and that obtained in the South Atlantic Ventilation Experiment (SAVE, late 1980s). In particular, they show that the volume of deep and bottom water in the class $\left(-0.25^{\circ} \mathrm{C}<\theta<-0.15^{\circ} \mathrm{C}\right)$ had decreased by 1988 , a feature that was most prominent in the southwest corner of the Argentine Basin. P. Saunders (personal communication, 1996) suggests that this warming trend has continued until 1992-1993 with a further increase of about $0.02^{\circ} \mathrm{C}$ in bottom water potential temperatures (based on the WOCE A11 section at $45^{\circ} \mathrm{S}$ ). In fact, by the time of the A11 section there remained no water along the deep western boundary colder than $-0.18^{\circ} \mathrm{C}$, whereas in the early $1980 \mathrm{~s}$ it had been as cold as $-0.22^{\circ} \mathrm{C}$.

A natural consequence of the northward flow in the western boundary current would be for this warming to appear in the Vema Channel region a few years later, although Coles et al. [1996] suggest that the signal had already reached the Brazil Basin by 1989 , again based on a comparison of SAVE with earlier data.

Accompanying this loss of the coldest bottom water, according to Coles et al. [1996], has been a freshening (and cooling!) of the $\theta-S$ along potential density surfaces below $1^{\circ} \mathrm{C}$. The Vema Channel data do not support this claim (Figure 6). The cruises for which good salinity calibrations exist fall within a fairly narrow envelope and show no trend toward lower salinities with time. The Marathon station is generally the freshest, although there is a portion of the Meteor 22 station which is even fresher.

As Reid et al. [1977] have shown, there do exist sizable spatial variations in deep water $\theta-S$ along isopycnals in this region. For example, on the $\sigma_{4}=46.13$ surface, variations within the Argentine Basin are of the order of $0.02 \mathrm{psu}$, substantially greater than the signal reported by Coles et al. [1996]. Hogg et al. [1982] report similar variations at the mouth of the Vema Channel which quickly disappear, presumably through mixing, within the channel.

Longer term changes in deep water properties are even harder to judge (Figure 6b). Sampling of salinities and temperatures by the original Meteor survey during the 1920s was crude by today's standards, but the available data suggest water properties closer to "typical" than those measured by the Marathon cruise.

The warming phenomenon extends from the Vema Channel eastward to the Hunter Channel and westward to the shallower region over the Santos Plateau. Based on geostrophic velocity estimates, it also appears to be accompanied by a reduction in transport of AABW [Zenk and Hogg, 1996]. These trends, derived from the Meteor 15 and 22 hydrographic data, are supported by the moored time series measurements (Figure 7). Over the nearly 2-year record, temperature warmed at the rate of $0.1^{\circ} \mathrm{C} / 1000$ days (Figure 7a) over the Santos Plateau. Note that this is warmer water than we have been discussing, although still within the AABW range (the correction to potential temperature is about $-0.3^{\circ} \mathrm{C}$ ). Upon entering the Brazil Basin through the Vema Channel, this water appears partially to recirculate over the Santos Plateau (Figure $7 \mathrm{~b}$ ). The sign of the record-averaged trend in the velocity component normal to the mooring line is such as to decelerate the flow almost everywhere. Zenk and Hogg [1996] show that the transport of $\mathrm{AABW}$, as calculated from the two hydrographic cruises spanning the moored records, is reduced from about $6 \mathrm{~Sv}$ to $4 \mathrm{~Sv}$, a $33 \%$ change that is not inconsistent with the change in velocities estimated from Figure 7.

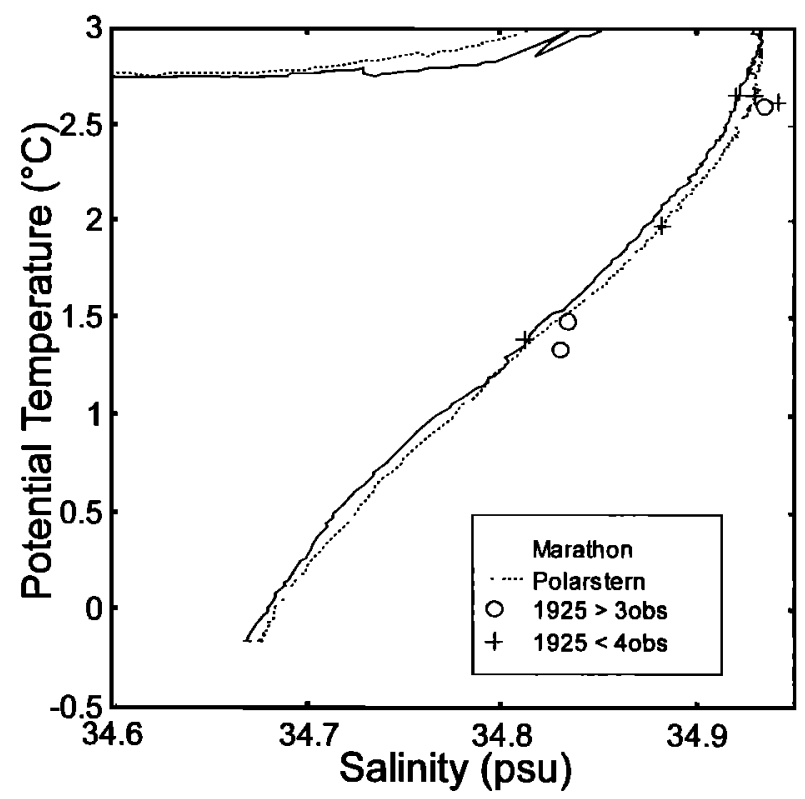

Figure 6b. As in Figure 6a for selected stations from the Thomas Washington Marathon, the $P o-$ larstern ANT XII and the original Meteor cruises in the Deutsche Atlantische Expedition. Data from the last are discrete, and the symbols indicate the number of titrations used for each salinity determination. 

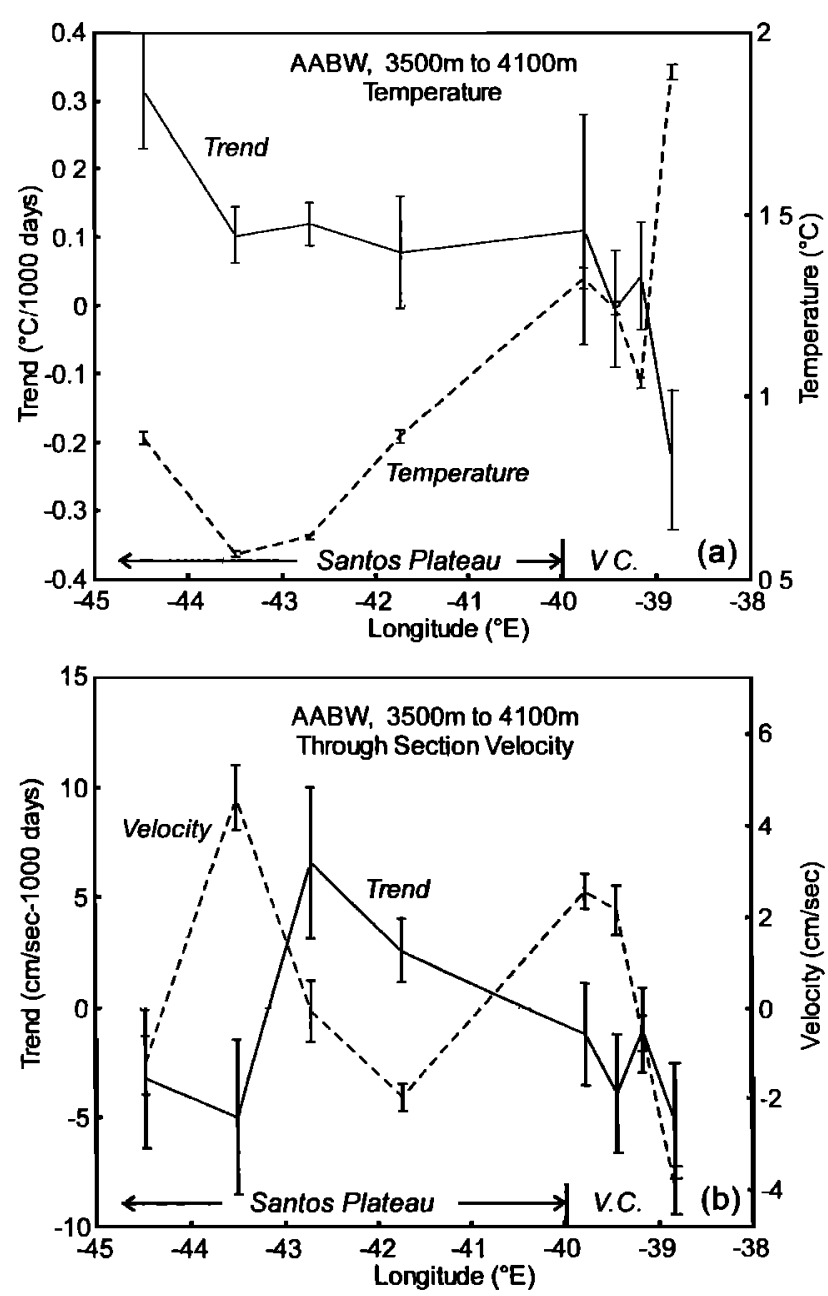

Figure 7. Trends in temperature and velocity time series calculated from those current meters that were positioned within the AABW over the Santos Plateau and in the Vema Channel during 1991 and 1992. Vertical error bars are approximate standard errors assuming a 10-day decorrelation time. (a) Temperature. (b) Crossarray velocity component.

\section{Conclusions}

The warming trend within the bottom water, first reported by Coles et al. [1996] using 1988 SAVE data within the Argentine Basin and then observed by Zenk and Hogg [1996] in the Vema and Hunter Channels and over the Santos Plateau in the early 1990s, ceased abruptly by 1992 , leaving the coldest bottom water about $0.03^{\circ} \mathrm{C}$ warmer than it had been during the previous two decades. At the same time there has been a measurable decrease in the northward bottom water transport.

Use of the adjective "warming" carries with it the connotation of possible climate change. It is not clear from our data that water masses are being warmed (setting aside possible $\theta-S$ changes reported by Coles et al. [1996]). Instead, it would appear that there has been a reduction in bottom water production (for our coldest temperatures this is Weddell Sea Deep Water accord- ing to Reid et al. [1977]). Such a decrease would be expected to lead to a corresponding decrease in western boundary transport, a reduction in the flow through the southern boundary of the Brazil Basin, and an associated relaxation of the horizontal temperature gradients with a resulting lowering of isotherms banked up against the western boundary and a consequent rise in bottom temperatures.

Acknowledgments. This work was supported by grants from the U.S. National Science Foundation (OCE-90-04396 and OCE-94-15509), the Deutsche Forschungsgemeinschaft (Si 111/38-1, Si 111/39-1), and Bundesministerium für Bildung, Wissenschaft, Forschung und Technologie (03F0535A, 03F0050D). Special thanks to Karen Heywood, Peter Saunders, and Yoshimine Ikeda for sharing their data with us and to Mindy Hall and two reviewers whose careful reading helped clarify the presentation. Woods Hole Oceanographic Institution contribution 9353.

\section{References}

Coles, V. J., M. S. McCartney, D. B. Olson, and W. J. Smethie Jr., Changes in Antarctic Bottom Water properties in the western South Atlantic in the late 1980s, J. Geophys. Res., 101, 8957-8970, 1996.

Heywood, K. J., and B. A. King, RRS James Clark Ross Cruise 10, 20th March - 6th May 1995, World Ocean Circulation Experiment, WOCE Hydrographic Programme One-Time Section A23, A Hydrographic Section from Antarctica to Brazil in the Southwest Atlantic, UEA Cruise Rep. Ser. 1, 75 pp., School of Environ. Sci., Univ. of East Anglia, Norwich, England, 1996.

Hogg, N. G., Hydraulic control and flow separation in a multi-layered fluid with applications to the Vema Channel, J. Phys. Oceanogr., 13, 695-708, 1983.

Hogg, N. G., P. Biscaye, W. Gardner, and W. J. Schmitz Jr., On the transport and modification of Antarctic Bottom Water in the Vema Channel, J. Mar. Res., 40, 231-263, 1982.

Johnson, D. A., S. E. McDowell, L. G. Sullivan, and P. E. Biscaye, Abyssal hydrography, nephelometry, currents, and benthic boundary layer structure in the Vema Channel, J. Geophys. Res., 81(33), 5771-5786, 1976.

Maurer, H., and T. Stocks, Die Echolotungen des Meteor, Dt. Atl. Exp. Meteor 1925-1927, Bd. 2, 309 pp., 1933.

McCartney, M. S., S. L. Bennett, and M. E. WoodgateJones, Eastward flow through the Mid-Atlantic Ridge at $11^{\circ} \mathrm{N}$ and its influence on the abyss of the eastern basin, J. Phys. Oceanogr., 21, 1089-1121, 1991.

Reid, J. L., W. D. Nowlin Jr., and W. C. Patzert, On the characteristics and circulation of the southwestern Atlantic Ocean, J. Phys. Oceanogr., 7, 62-91, 1977.

Speer, K., and W. Zenk, The flow of bottom water into the Brazil Basin, J. Phys. Oceanogr., 23, 2667-2682, 1993.

Tarbell, S., R. Meyer, N. Hogg, and W. Zenk, A moored array along the southern boundary of the Brazil Basin for the Deep Basin Experiment - Report on a joint experiment 1991-1992, Tech. Rep. WHOI-94-07, Woods Hole Oceanogr. Inst., Woods Hole, Mass., 1994. (Also published as IfM-Kiel 243, 107 pp., Berichte aus dem Inst. für Meereskunde an der Christian-Albrechts-Univ.-Kiel, 1994.)

Whitehead, J. A., Critical control by topography - deep passages, straits, and shelf fronts, in Topographic Effects in the Ocean, SOEST Spec. Publ., Proceedings, 'Aha Huliko'a, Hawaiian Winter Workshop, University of Hawaii at Manoa, January 17-20, 1995, edited by Peter Müller 
and Diane Henderson, pp. 144-156, School of Ocean and Earth Science and Technology (SOEST), Univ. of Hawaii at Manoa, Honolulu, Hawaii, 1995.

Zemba, J. C., The structure and transport of the Brazil Current between 27 and $36^{\circ} \mathrm{S}$, Ph.D. thesis, 160 pp., MIT/WHOI Joint Program in Oceanogr. and Oceanogr. Eng., Woods Hole, Mass., 1991.

Zenk, W., and N. G. Hogg, Warming trend in Antarctic Bottom Water flowing into the Brazil Basin, Deep Sea Res., 43, 1461-1473, 1996.

Zenk, W., K. G. Speer, and N. G. Hogg, Bathymetry at the Vema Sill, Deep Sea Res., 40, 1925-1933, 1993.
N. G. Hogg, Department of Physical Oceanography, Clark Laboratory 3, Mail Stop 21, Woods Hole Oceanographic Institution, Woods Hole, MA 02543-1541. (e-mail: nhogg@whoi.edu)

W. Zenk, Institut für Meereskunde an der Universität Kiel, Düsternbrooker Weg 20, 24105 Kiel, Germany. (email: wzenk@ifm.uni-kiel.de)

(Received September 17, 1996; revised December 6, 1996; accepted January 30, 1997.) 